\title{
Building brands through alternative brand contact communications
}

\author{
Ernest North and Carla Enslin
}

\begin{abstract}
For many customers and consumers, the brand 'is the product'. Managers and marketing specialists therefore consider branding as a key strategic tool used to create awareness, reputation and build the organisation's image. The brand image results from contacts that stem from both the marketing and communications domains. To develop a synergistic brand identity all levels of consumer interaction or contact with the brand must be addressed and not only those delivered through planned marketing communications efforts. The purpose of this article is to provide an overview of the theory underlying the perceived nature and role of alternative brand communication contacts, within the context of the outside-in integrated brand contact approach in the South African marketing and communications industry. Certain propositions will be formulated to serve as stimuli that can be used to critically assess the inclusion of alternative brand communications techniques as an extra function of Integrated Marketing Communications (IMC). Suggestions for future research will be offered.

Vir baie verbruikers en kliente is die handelsmerk die 'produk'. Bestuurders en spesialiste in bemarking beskou die handelsmerk dus as 'n kern strategiese wapen wat aangewend word om bewuswording en reputasie te bou en die organisasie se beeld te vestig. Die handelsmerkbeeld het sy oorsprong in kontak wat uit beide die bemarkings- en kommunikasiedomeine voortvloei. Die ontwikkeling van die handelsmerkidentiteit op ' $n$ sinergistiese wyse vereis dat alle vlakke van kontak en interaksie met die handelsmerk aangespreek word. Die doel van hierdie artikel is om ' $n$ oorsig te gee van die teorie wat die aard en rol van altematiewe handelsmerk kommunikasie-kontakte, in die konteks van die uitwaartse-in, geTntegreerde handelsmerk kommunikasie in die Suid Afrikaanse bemarkings- en kommunikasie-industrie, onderle.
\end{abstract}

\section{Introduction}

There is general agreement in the business and marketing literature that a brand is more than the name given to a product; it embodies a whole set of physical and sociopsychological attributes and beliefs (Simes \& Didd 2001:217). In consumer marketing, brands often provide the primary means of differentiation between competitive offerings and can therefore be critical to the success of companies. It is estimated that half of the market value of the Fortune 250 companies is tied up in intangible assets such as brand equity (Court, Leiter \& Loch 1999:101).

In today's volatile and competitive markets, brands are under constant pressure. Mergers, acquisitions and major changes in the business environment demand the continuous management of the organisation's brands. All brands, 'whether product, service or corporate require constant evaluation and conscious rejuvenation' (McCoy 2001:1). For 
many customers and consumers, the brand is the product'. Therefore, branding is a key strategic tool used by marketers to communicate with consumers, and to create awareness, reputation and build the organisation's image. Ries and Ries (1998:77) claim that a company's very existence today depends on building brands. Quoted in The Economist, Clift (2001:30), asserts that brands are the ultimate accountable institution. 'If people fall out of love with your brand, you go out of business.'

As an element of the marketing mix, the role of promotion or marketing communications is to communicate product or service information, and specifically the value and benefits of a certain brand to potential customers. The primary goal of all marketing communication efforts is to inform, persuade and remind the target market of the product (brand) and/or service benefits, with the objective of influencing their attitudes and consumption behaviour. The role and scope of marketing communications have classically been defined in context of the promotional mix (Rix \& Stanton 1998; Belch \& Belch 2001; Duncan 2002), consisting of the following elements: advertising, personal selling, sales promotions techniques, direct marketing and public relations/publicity. In the literature these five elements are referred to as Integrated Marketing Communications (IMC).

In a recent study van Heerden (2001:50-67) investigated the role and importance of sponsorships in the South African sporting industry. After an intensive literature study, he concluded that there is total confusion with respect to the positioning and role of the IMC elements, for example public relations and sponsorships. One of the recommendations of the study is that sponsorships should be added as an element of IMC. The purpose of this article is to provide an overview of the theory underlying the perceived nature and role of alternative brand communication contacts, within the context of the outside-in integrated brand contact approach in the South African marketing and communications industry. Certain propositions will be formulated to serve as stimuli that can be used to critically assess the inclusion of alternative brand communications techniques as an extra function of or element of IMC. Suggestions for future research will be offered.

\section{Marketing communications in context}

The development of a marketing strategy involves the planning and implementation of an overall marketing offer, to appeal to defined groups of consumers and/or organisations with whom a business wants to create marketing exchanges and develop long-term relationships. According to Bearden, Ingram and LaForge (2001:10), the process of strategy development involves decisions in primarily four areas, namely product and brand development, pricing, distribution and marketing communications. These decisions are effectively blended into a marketing mix designed to serve the target market.

The role of marketing communications according to Burnett and Moriarty (1998:3), as a function of the marketing mix, is to communicate product or service information to 
potential customers. Communication efforts aim to inform, persuade and remind the target market of the product (brand) and/or service benefits, with the objective of influencing their attitudes and consumption behaviour. It is clear, therefore that marketing communications play a vital role in brand building. The above-mentioned IMC elements are used to communicate with, and persuade target audiences to buy and ultimately become loyal to products/brands and services. Each of these promotional methods or tools has distinct features that determine the strategic context in which it will be most effective.

- Advertising. According to Bearden, Ingram and LaForge (2001:393), advertising is the activity that consumers most associate with the term marketing. Arens (2002:7) defines advertising as 'the structured and composed nonpersonal communication of information, usually paid for and usually persuasive in nature, about products (goods, services and ideas) by identified sponsors through various media'. Advertising generally involves the buying of space and time in mass media (such as TV, radio and magazines) to communicate messages to large audiences, often at the same time. According to Duncan (2002:511) advertising adds value to a brand by creating brand awareness, long-term brand images and brand positions.

- Personal selling. Unlike advertising, personal selling involves interpersonal communication in which a seller's objective, according to Belch and Belch (1998:21), is to 'assist and or persuade prospective buyers to purchase the company's product or service or to act on an idea'. The two-way flow of communication between a seller and buyer is deliberately designed to influence the buyer's purchase decision. The power of personal selling resides in the ability to customise the product offering and communications appeal and to deliver an immediate response to customer feedback.

- Direct marketing. Like personal selling, direct marketing is an interactive promotional tool with the ability to personalise communication messages and gain customer feedback. Duncan (2002:600) explains that direct marketing is a 'closed-loop, interactive, databasedriven messaging system that uses a broad range of media to create a behavioral response'. Duncan (1995:7) states that the primary aim of the customer database is to profile customers and track their behaviour. Direct marketing communication can take on many forms, including direct mail, catalogue marketing, telemarketing, direct response advertising and on-line marketing.

- Sales promotions. Sales promotions aim to stimulate immediate sales by providing extra value or incentives to the sales force, distributors or the ultimate consumer. Kotler (2000:661) states 'where advertising offers a reason to buy, sales promotion offers an incentive to buy'. Sales promotional activities are specifically employed by marketers to perform well in the short term. This promotional tool involves the development and implementation of both trade-orientated (push) strategies for example, price and performance deals, display allowances and cooperative advertising; and consumerorientated (pull) strategies, for example, price promotions, competitions and samples. 
- Public Relations and Publicity. The function and practice of public relations, according to Dozier, Grunig and Grunig et al. (1995) entails the 'management of communication between an organisation and its publics.' Public relations includes a broad range of diverse activities with the core objective of creating or building public goodwill. Corporate identity, advertising, internal company communications, publicity, sponsorship and event marketing, and customer relationship and social responsibility programmes, all form part of the vital process of promoting the vision of an organisation. As mentioned above, Van Heerden (2001) is of the opinion that sponsorships should not be seen as part of the public relations function.

According to Belch and Belch (2001:12) a company combines the promotional mix elements by balancing the strengths and weaknesses of each, to develop an effective promotional campaign. Communication with the firm's customers will be more effective if it utilises the synergy between the various promotional tools.

The function of marketing communications is core to the process of brand building. Kapferer (1997:15) observes that the newly found power in brands is confirmed by the increasing importance that so many marketers place on the promotion of their own brands. Marketing communication is recognised as a powerful tool in defining and building the identity of a brand. The essential aim of marketing communications, as Ries and Ries (1998:4) conclude, is to build a brand in consumers' minds. Berkowitz, Kerin, Hartley and Rudelius et al. (2000:502) observe that in the past the promotional elements were regarded and treated as separate functions, by experts in separate departments. The result was an uncoordinated and inconsistent communication effort. Brand strategists and academics now reason that the various tools need to work together to present an integrated brand identity. Communication messages that are delivered through the spectrum of promotional tools must be coordinated to present a consistent brand message to customers and consumers.

This outlook resulted in the birth of the concept of Integrated Marketing Communications. The move towards IMC is described by Belch and Belch (1998:11) as one of the most significant marketing developments of the 1990s. The American Association of Advertising Agencies (the 4 A's) defines IMC as 'a concept of marketing communications planning that recognises the added value of a comprehensive plan that evaluates the strategic roles of a variety of communication disciplines - for example, general advertising, direct response, sales promotion, and public relations - and combines these disciplines to provide clarity, consistency, and maximum communications impact' (Schultz 1993:17). The intent is to develop a marketing communications plan in which the communication disciplines work together as an integrated whole, to achieve maximum communications impact and deliver a consistent brand identity.

As stated earlier, authors are not in agreement when it comes to the tools or elements to be used in the promotional IMC mix. Table 1 is a summary of the views of some authors 
(published after the turn of the century) on the elements they consider to be part of the promotional mix.

Table 1 Elements of the promotion mix

\begin{tabular}{|l|l|l|l|l|l|l|l|}
\hline $\begin{array}{l}\text { Authors/ } \\
\text { Elements }\end{array}$ & $\begin{array}{l}\text { Advertis- } \\
\text { ing }\end{array}$ & $\begin{array}{l}\text { Direct } \\
\text { market- } \\
\text { ing }\end{array}$ & $\begin{array}{l}\text { Sales } \\
\text { promo- } \\
\text { tion }\end{array}$ & $\begin{array}{l}\text { Public } \\
\text { relations }\end{array}$ & $\begin{array}{l}\text { Personal } \\
\text { selling }\end{array}$ & $\begin{array}{l}\text { Interac- } \\
\text { tive/ } \\
\text { Internet }\end{array}$ & $\begin{array}{l}\text { Events/ } \\
\text { Sponsor- } \\
\text { ships }\end{array}$ \\
\hline $\begin{array}{l}\text { Kotler } \\
\text { (2000) }\end{array}$ & Yes & $\begin{array}{l}\text { Yes } \\
\text { (Internet) }\end{array}$ & Yes & Yes & Yes & & \\
\hline $\begin{array}{l}\text { Belch \& } \\
\text { Belch } \\
\text { (2001) }\end{array}$ & Yes & Yes & Yes & Yes & Yes & Yes & Yes \\
\hline $\begin{array}{l}\text { Peter \& } \\
\text { Donnelly } \\
\text { (2001) }\end{array}$ & Yes & & Yes & Yes & Yes & & \\
\hline $\begin{array}{l}\text { Lamb et } \\
\text { al. (2002) }\end{array}$ & Yes & & Yes & Yes & Yes & & \\
\hline $\begin{array}{l}\text { Duncan } \\
\text { (2002) }\end{array}$ & Yes & Yes & Yes & Yes & Yes & Yes & Yes \\
\hline
\end{tabular}

The key question to answer here is whether there is merit in the inclusion of alternative (outside-in) brand communication contacts as an extra IMC element, and will this contribute towards the cause of effective brand communications impact?

\section{The nature and scope of alternative brand contact}

The denotative meaning of the word 'alternative' defines the choice between two or more things; the use of one of two or more possibilities. The word has evolved however to refer to institutions, systems or thinking that is nontraditional, for example alternative media and alternative journalism. Holhut (2001:5) states that alternative journalism, for example, aims to challenge and liberate mainstream media.

Duncan (2002:138) points out that the concept of brand contact was first popularised by Jan Carlson, former chairman of Scandinavian Airlines Systems (SAS), who coined the term 'moments of truth'. All situations, where consumers or customers have the opportunity to be exposed in some way to a brand message, whether initiated or uninitiated, establish a moment of brand truth. The interpretation of the word alternative in marketing communications is, however, indicative of traditional inside-out thinking. The concept is applied in the context of media classifications, to refer to the difference and choice between, for example, above-the-line mass media and 'alternative' below-the-line promotional tools, such as sales promotions and direct marketing. Rossiter and Percy (1997:8) state that in IMC the media choices extend beyond conventional advertising to 
include sales promotion media, such as sampling, coupons, or loyalty programmes; corporate Pubic relations (PR) media, such as press releases, special events, or sponsorships; and direct response media, such as direct response advertisements in mass media, or by mail, by telephone, at home, or at the point of purchase.

Differentiating between traditional above-the-line mass media, and below-the-line, alternative communication media is indicative of classical inside-out thinking. The brand and its points of contact must be viewed from the outside-in, in other words, through the eyes of the customer, prospective consumer and other stakeholders. In the context of the outside-in and zero-based contact planning philosophy, advocated by Drucker in Webster (1994:7), Schultz and Barnes (1995:3-8), Duncan (1995:5), Ries and Ries (2000:108), Belch and Belch (1998:10) and Hofmeyr and Rice (2000:29), alternative brand contacts are defined as those contacts that are experienced as unconventional and unexpected by the consumer. The nature of contact with the consumer establishes the alternative appeal and not the use of one medium as opposed to another. The alternative contact is not bound by media type and is, therefore, in keeping with the zero-based planning approach, media neutral. The strategic challenge and qualifying factor is the unconventional and unexpected experience of the point of contact, whether in a traditional or nontraditional media environment. In support, Aaker and Joachimstahler (2000:295) observe that it is by implementing 'familiar programmes in an innovative way or by creating new programmes' that alternative brand building is effectively introduced. From the discussion above, the question can be asked as to whether communication managers consider the unexpected and unconventional point of brand contact to be media neutral and applicable for implementation in both traditional and nontraditional media.

According to Sampson (2000:66) the opportunity to attract attention and use it to good effect must never be wasted and, as Oosthuizen (2000:52) puts it, every conceivable opportunity to explode the presence of the brand into the identified target markets must be exploited. Harris, in Chronis (2000:67), argues that alternative contacts achieve exactly this: 'They are head turners, popping up when they are least expected.' The alternative brand contact, in keeping the assessment by Blackwell, Miniard and Engel (2001:446) of incongruent stimuli, is noticed and achieves impact because it deviates from expected brand contact points. The alternative point of brand contact draws attention because it is incongruent with expected brand communications activity.

It is within the context of the new media environment that the concept of ambient media is introduced. The word ambient defines that which surrounds, encircles or envelops. Ambient media aim to penetrate the environments with which consumers routinely interact to create unconventional and unexpected points of brand contact. Horton (2001:2) and Phillipson (2001:6-8) explain that ambient media are introduced to have an impact on consumers in the spaces where they live their lives. The Future of Media (Future 2000:42, 49,52 ) highlights the growth of alternative contact opportunities and specifically new 
ambient media owners in South Africa. The company Graffiti has, for example, evolved the outdoor media offering of introducing branded student cars, taxi tops and golf carts. The Forecourt Television Network (FTN) has launched large screens on petrol forecourts where satellite-based technology transmits programmes and advertisements. The Inline Indoor Media Company positions their alternative brand contacts in foyer and lobby areas throughout cinemas and airports on a national basis. It is important to note that effective impact will best be achieved because the novelty of the alternative brand contact situation has attracted the consumer's attention. Following the discussion above, communication managers need to know if, the novelty of the alternative brand contact will attract the attention of consumers and to what extent?

\section{Sources of brand contact}

The brand is a focal point for all the impressions created by consumers over time. These impressions result from a myriad of consumer contacts with the brand. To build a focused brand identity, it is vital that all the points of contact consistently communicate and reinforce the single-minded positioning of the brand. Duncan and Moriarty (1997:78) and Duncan (2002:129), indicate that points of brand contact primarily stem from four major sources of brand messages. These are planned, product, service and unplanned messages (North \& Enslin 2003).

- Planned points of brand contact are encountered in the traditional scope of marketing communications. The notion of IMC originated with the strategic intent to build a consistent brand identity through advertising, sales promotions, public relations, direct marketing and personal selling. Duncan and Moriarty (1997:78) reason that consistency in brand identity development is more readily achieved in this domain, because brand communication messages are deliberately planned and can be controlled.

- Product related points of brand contact present messages that are inferred from the product itself, such as its appearance and performance, the points of distribution and the pricing as a cue of product quality. Price and distribution, for instance, are often not considered as brand building elements. Price and distribution, however, position a brand, stating how the brand compares to competitor offerings. The frequency and extent of price promotions communicate a great deal about the brand. For example, the more a brand is on sale and the greater the discounts are, generally the more ordinary the consumer considers it to be (Duncan, 2002:132).

- Brand messages furthermore originate from service contacts shaped through personal interactions with an organisation and its employees. Service contacts wield considerable influence as they usually involve personal interaction, which as Duncan and Moriarty (1997:84-85) reason, is the most persuasive form of communication. A service that is correctly delivered is ultimately a fulfilled promise. Service contacts are furthermore particularly powerful because they involve real-time interfaces between a company and a customer or consumer. 
- Many contact points deliver further unplanned brand messages for example, actions, findings, rumours and comments by the trade, employees, government, research institutions, the media, competitors and interest groups that often lead to publicity and word-of-mouth. Clift (2001) observes that new technology such as e-mail has furthermore empowered the scope and speed with which unplanned contacts are delivered. Publicity and word-of-mouth are fully leveraged in the virtually connected world. These points of contact are also particularly difficult to control, as Duncan (2002:135) points out, because they often come from sources outside of the company. A further challenge facing communication planners is to ensure that alternative brand contact strategies do not rely on novelty alone. Therefore, to create meaningful impact, they need to know how to ensure that the content of the alternative brand contact message will communicate a relevant, distinctive and single-minded positioning of the brand.

\section{The growth of alternative brand contact implementation}

Secondary research indicates that there are several core reasons for the growth in alternative points of brand contact. An integrated assessment reveals two primary motivators. The first of these is clients' demand for not only greater accountability, but also a higher level of innovation in brand contact planning. A second powerful motivator is encountered in the brand communications environment. To achieve impact, points of brand contact need to succeed in cutting through increasing levels of commercial clutter. The alternative brand contact addresses this challenge.

\subsection{Client demand for innovative contact planning}

Oosthuizen (1996:35), Curtis (2001:138) and Phillipson (2001:6) assert that clients are increasingly seeking brand communications solutions beyond the tried and trusted, mostly traditional, brand communication methods. According to Kelly and Liftman (2002:3) the single biggest trend in the corporate world today is the acknowledgement of innovation as the critical construct in the development of strategies and initiatives. This is particularly true for the field of brand communications. Herber (2000:7; 2001:78) warns that brand communications that merely deliver more of the same, in repackaged form, are bound to fail. Brand communication or contact plans must contribute new strategic ideas and contact innovation.

\subsection{Breaking through commercial clutter barriers}

The second key motivator to alternative brand contact planning is encountered in the consumer's experience of the brand communications environment. Hollis (2001:50) observes that consumers are inundated by commercial messages, more so than ever before. Advertising surrounds consumers wherever they go, and, to cope with the communication clutter, consumers construct defense mechanisms. They 'tune-out' during commercial breaks on television or regress into channel switching mode, and this 
communication noise has resulted in unique media and message behaviour. Duncan and Moriarty (1997:91) reason that consumers have come to condition themselves mentally to ignore traditional advertising messages. Belch and Belch (1998:113) and Duncan (2002:144), confirm that consumers more aggressively apply selective exposure and selective attention measures.

Communication clutter adversely affects the erection of selective exposure and attention barriers. The likelihood that a point of brand contact will achieve exposure and receive attention diminishes as the level of communication noise increases. Duncan (2002:144) observes that as soon as consumers recognise something as a commercial message, they try to block it out or change to another television station. As fields of brand communication contact become more recognisable and cluttered, consumers increasingly erect more intensive selective exposure and attention measures.

According to Bearden, Ingram and LaForge (2001:374) the challenge is to move beyond, or to manipulate traditional communication vehicles to target consumers in an unconventional manner when and where they least expect to encounter a commercial message and when they are in a susceptible state of mind. This is the essence of alternative brand contact planning, which leads to the following question: to achieve impact, how can the communication planner ensure that the alternative brand contact is relevant to the consumer, both in terms of lifestyle patterns and interest, and state-of-mind (aperture)?

\section{Creative strategic thinking in alternative brand contact planning}

Alternative brand contact planning requires innovative thinking and the introduction of creative strategic planning, which enompasses methods such as the process of disruption, creativity and media fragmentation.

\subsection{The process of disruption}

Dru (1996:35, 54, 56) addresses the need for developing alternative strategic communication approaches and grounds his approach in the formulation of an alternative concept and process of disruption: 'disruption is about finding the strategic idea that breaks and overturns a convention in the marketplace, when the planner rejects using a familiar approach.' The result is a novel concept based on strategic creativity. Dru presents a threestep process to disruption. Firstly, the conventional communications activity surrounding the brand must be investigated. The aim is to identify the strategic ideas and activity that maintain the status quo and that are, as a result, hardly noticed because of their familiarity. Kelley and Liftman (2002:6) assert that it is therefore necessary to gain insight into consumers in their real life experience of the environment to understand what confuses them, what they like, and what they hate. Insight into conventional brand communications patterns and how consumers experience them presents a platform upon which teams, as 
Aaker and Joachimsthaler (2000:297) conclude, can engage in creative thinking exercises to identify innovative communication concepts.

In the second step, disruption is applied. Past and current strategic methods are questioned to develop new hypotheses and strategic ideas. Unexpected and unconventional brand communication ideas on both a strategic contact and creative message level are carefully pursued. Disruption requires that creative strategic thinking be applied in order to achieve a diliberate break with conventional strategic methods. The challenge, according to Hamel (1996:80), is to search for discontinuities that will present a revolutionary idea, an unconventional strategic option. In keeping with the integrated brand contact methodology, the third step stresses the importance of identifying alternative concepts that will most effectively communicate the brand positioning strategy (brand integration). Dru (1996:58) agrees with Hollis in Chronis (2000:65), confirming that the alternative concept must contribute to the overall brand contact strategy in the building of a singleminded, integrated brand identity.

Dru's theory on disruption also emphasises that in order to introduce an unconventional and unexpected point of brand contact, the account team must move outside-in to gain insight into the communication norms surrounding the brand. Moving outside-in to investigate consumer perceptions of brand communications, as Dru (1996:87) submits, presents the source of disruption. An alternative point of contact will only emerge as insights and opportunities are further explored and creative strategic thinking is applied.

\subsection{The role of creativity}

The planners of points of brand contact cannot rely solely on the creativity of the communication message to break through commercial clutter. Creative strategic thinking must be applied to introduce unconventional and unexpected points of brand contact. According to Sternberg and Lubart (1999:3), creativity is the ability to produce that which is both novel (i.e. original, unexpected) and appropriate (i.e. useful, adaptive).

Insight into the consumer's experience of the brand communications environment must therefore be applied to formulate brand communication problems or challenges. Creative strategic thinking is introduced to deliver alternative perspectives and solutions to the defined brand communication challenges. The ultimate goal is to create alternative points of brand contact that are novel and appropriate to the overall brand contact strategy. Rossiter and Percy (1997:181) assert that the challenge is to present an idea that is attention-getting and catalytically relevant to the brand position.

Schultz and Barnes (1995:174) introduce the concept of controlled creativity in this regard. The objective is to deliver creative ideas that not only draw attention, but also communicate effectively with target audiences. Nickerson (1999:400) proposes that structured approaches be introduced to undertake creative problem-solving. Brainstorming, first introduced by Osborn (1953), is for example, a creative problem-solving tool 
specifically designed for groups. According to Nickerson (1999:402) brainstorming is essentially a search process specifically aimed at delivering innovative and useful ideas. The Cognitive Research Trust founded and directed by De Bono, focuses particularly on lateral thinking in creative problem-solving. De Bono (1971:4) describes lateral, as opposed to traditional, logical vertical thinking, as discontinuous in nature. Lateral thinking seeks to explore new relationships among elements, situations, events and activities, to develop new and unique ideas. De Bono (1971:50-5) identifies several methods to stimulate lateral thinking. For example, teams can for example, generate alternatives to current situations, challenge present assumptions, apply incubation, develop analogies for situations and undertake brainstorming.

\subsection{Fragmentation in traditional media environments}

According to the ambient media owners, media fragmentation is a key trend in the development of alternative points of brand contact. Gordon-Brown (2000:30) points out that since 1995, 135 new consumer magazines (mostly niche titles), and 144 new business-to-business magazines have been launched in South Africa. Media fragmentation introduces niche-marketing opportunities but also increases customer choice and inevitably raises communication clutter levels. The growth of new ambient media owners is indicative of the search for alternative points of brand contact. This trend is, however, also noticeable in the traditional media environment. Walker's (2000:3) analysis of global media trends and specifically the growth of alternative brand contacts, stresses the increasing development of unconventional techniques in traditional media. Alternative points of brand contact, as previously argued, can be introduced in the form of new points of contact beyond the traditional media, or as unconventional and unexpected points of contact within the traditional media.

Global media owners and brand communication planners are becoming receptive to novel brand contact ideas (Walker, 2003:3). Audi, for example, won a Lion Award at the Cannes Advertising Festival in 2000 for their use of bubble wrap covers on magazines, to advertise the benefit of Audi airbags. Walker observes that global receptiveness to 'stunts, innovation and unusual treatments of traditional media types' is growing. The increase in alternative brand contact approaches on television and in cinema further illustrates this trend. Product placement is for example, viewed by Duncan (2002:406), as a unique way to reach mass communication audiences. The sponsored integration of brands into television programming and cinema movie content, delivers an alternative contact to the conventional television or cinema advertisement. Reebok and Pepsi for example, featured in the reality show, Survivor: The Australian Outback. Liqui Fruit applied the same principle locally, by integrating their range of fruit juices into the programming content of Big Brother South Africa.

Another form of product placement entails prominent exposure of the brand. The BMW model Z28 was launched in the James Bond film, The world is not enough. Close-up 
scenes of Bond driving the car left no doubt as to the brand. The Mercedes-Benz M-Class all-activity vehicle was likewise launched in the film The Lost World: Jurassic Park. Prominent brand exposure in television programming or cinema releases ensures that the brand enjoys a starring role in the context of actual content. A like-minded, and perhaps more unconventional approach to product placement, is followed globally by Nike. As opposed to integrating products into editorial content the brand message is transformed into editorial content. Nike penetrates Mtv programming content with brand messages that resemble music videos. The music video is an unexpected and unconventional means of communicating the Nike brand message (Elliott 2001:1).

\section{Conclusions and directions for future research}

The following general statement serve as a guide to formulating specific propositions that can be used for future studies in this field: 'The unconventional and unexpected point of brand contact breaks through commercial clutter barriers to impact on consumers and communicate or reinforce the single-minded positioning of the brand.' The specific propositions are set out below:

P1: The unexpected and unconventional point of brand contact is media neutral and applicable for implementation in both traditional and nontraditional media.

P2: To achieve impact, the alternative brand contact must firstly be novel to be noticed.

P3: To create meaningful impact, the alternative brand contact must, in message content and form, communicate a relevant, distinctive and single-minded positioning of the brand.

P4: To achieve impact, the alternative brand contact must be relevant to the consumer, both in terms of lifestyle patterns and interest, and state-of-mind (aperture).

P5: Alternative brand communications techniques should be added as an element in the promotional mix.

The concept of alternative brand contact planning, in context of the outside-in brand contact and communication planning approach, offers a holistic and new understanding of brand building strategy. In the light of the transformation taking place in South Africa at present and the changing face of the general consumer profile, this approach should deliver a fresh and much needed perspective to the local communications industry. Brand and communication planners will be challenged to evaluate the relevance and impact of currently employed communication methods, and should be stimulated to explore unconventional brand communication approaches. It is suggested that future studies concentrate on qualitative research techniques such as focus groups and in-depth interviews with brand contact managers, to assess the value, planning and implementation 
of alternative brand communications techniques in the South African communications industry.

Further, it will be of value to launch an empirical study that investigates the perceptions of the consumer toward the alternative brand contact and the possible influence of the unconventional and unexpected contact strategy on consumer behaviour. And it is believed that the principle and premise of alternative brand contact planning is also applicable to service points of brand contact. The proposition is that unconventional and unexpected service contacts can break through commercial clutter barriers to impact on consumers, to communicate or reinforce the single-minded positioning of the brand.

\section{References}

Aaker, D. A. and Joachimsthaler E. 2000. Brand leadership. New York: The Free Press.

Arens, W. F. 2002. Contemporary advertising. New York: McGraw-Hill.

Bearden, B. Ingram T. and LaForge, B. 2001. Marketing principles and perspectives. 3rd ed. New York: McGraw-Hill.

Belch, G. E. and Belch, M. A. 1998. Advertising and promotion. An integrated marketing communications perspective. 4th ed. USA. Irwin/McGraw-Hill.

-. 2001. Advertising and Promotion. An Integrated Marketing Communications Perspective. 5th ed. USA: Irwin/McGraw-Hill.

Berkowitz, E. N., Kerin, R. A., Hartley S. W. and Rudelius W. 2000. Marketing. 6th ed. New York: McGraw-Hill.

Blackwell, R. D, Miniard, P. W. and Engel J. F. 2001. Consumer behavior. 9th ed. Orlando, Florida: Harcourt College Publishers.

Bumett, J. and Moriarty, S. 1998. Marketing communications. An integrated approach. New Jersey: Prentice-Hall.

Clift, S. 2001. Building global brands. Financial Mail Adfocus Conference, May 152001.

Court, D. C., Leiter, MG. and Loch, M. A. 1999. Brand Leverage. The McKinsey Quarterly (2):101110.

Curtis, G. 2001 in: Pulling The rug from the dinosaurs. AdFocus/Supplement to the Financial Mail, 2001:138.

de Bono, E. 1971. Lateral thinking For management. New York: American Management Association.

Dozier, M., Grunig, L. and Grunig, J. 1999. Manager's guide to exellence in public relations and communication management. New Jersey: Lawrence Erlbaum Associates, Inc.

Dru, J. 1996. Disruption. Overturning conventions and shaking up the marketplace. New York: John Wiley \& Sons.

Drucker, P. 1994. In Market driven management, ed. F Webster New York: John Wiley \& Sons.

Duncan, T. 1995. The Concept and Process of Integrated Marketing Communication. IMC Research Journal, Volume 1 Number 1:3-10.

-. 2002. IMC using advertising and promotion to build brands. New York: McGraw-Hill.

Duncan, T. and Moriarty, S. 1997. Driving brand value. New York: McGraw-Hill.

Elliot, S. 2001. Nike Ad Blurs into music video. The New York Times On The Web. www.nytimes.com 10 April. 
Gordon-Brown, C. 2000. Into The Gap. The future. The future of media supplement, 2:30.

Hamel, G. 1996. Strategy as Revolution. The Harvard Business Review, July-August:69-82.

Harris G. 2000. A Good Alternative. In The Future. The future of media supplement, ed. M. Clhronis 2:64-67.

Herber, H. 2000. Media: The Future? The Future. The Future of Media supplement, 2:6-7.

Holhut, T. 2001. A brief history of american alternative journalism in the twentieth Century. http://www.brasscheck.com/seldes/history.html. October: 1-8.

Hollis, V. 2000. A good alternative. In The Future. The Future of Media supplement, d. M. Chronis 2:64-67.

Hollis, V. 2001. Too many Media? Advantage with Advertising Age, January: 50.

Horton, B. 2001. Ambient: public perception. World Advertising Research Center \& Admap Seminar. October: London.

Kapferer, J. N. 1997. Strategic brand management. London: Kogan Page.

Kelly, T. \& Littman, J. 2002. The art of innovation. London: Harper Collins.

Kotler, P. 2000. Marketing Management. New Jersey: Prentice-Hall.

Lamb, C., Hair, J. and McDaniel, C. 2002. Marketing. 6th ed. Cincinnati: South-Western Publishing.

McCoy, S. 2001. KSDP. Johannesburg: Strategic Brand Consultants.

Nickerson, R. S. in: Sternberg, R. J. ed. 1999. Enhancing creativity. Handbook of creativity. UK: Cambridge University Press.

North, E., and Enslin, C. 2003. Alternative brand contact communications: About extending the promotional mix. The International Journal of Applied Marketing 2(2):4-24.

Oosthuizen, T. 1996. Ad industry myopia. Advantage with Advertising Age, February 1996:35.

-. 2000. Has Branding come to the end of the road? In The encyclopaedia of brands \& branding in South Africa. Year 2000 Edition. Sunday Times.

-. 2000 in: The times they are a changing. Adfocus/Supplement to the Financial Mail, May 19 2000:62-64.

Osborn, A. F. 1953. Applied imagination. New York: Scribner.

Peter, J. and Donnelly J. 2001. Marketing management. 6th ed. Boston: McGraw Hill.

Phillipson, G. 2001. Ambient media. The client's perspective. World Advertising Research Center \& Admap Seminar. October: London.

Ries, A. 1997. The future of your company depends on IT. London: Harper Collins.

Ries, A. and Ries L. 2000. The 22 Immutable Laws Of Branding. London: Harper Collins.

Rix, P. and Stanton, WJ. 1998. Marketing: A practical approach. 3rd ed. Australia: McGraw-Hill.

Rossiter, J. R. and Percy, L. 1996. Advertising communications \& promotion management. 2 nd ed. USA: McGraw-Hill.

Sampson, J. 2000. Corporate brands come into their own. In The Encyclopaedia of brands \& Branding in South Africa. Year 2000 Edition. Sunday Times.

Schultz, D. E., Tannenbaum, S. I. \& Lauterborn. 1993. Integrated marketing communications. Illinois: NTC Business Books.

Schultz, D. E. and Barnes, B. 1995. Strategic advertising campaigns. 4th ed. Illinois: NTC Business Books.

Simes, C. and Dibb, S. 2001. Rethinking the brand concept: new brand orientation. Corporate Communications: An International Journal 6(4):217-224. 
Sternberg, R. J. and Lubart, T. I. in: Sternberg RJ (Ed.) 1999. The Concept of creativity: Prospects and paradigms. Handbook of Creativity. UK: Cambridge University Press.

The future of media 2000 on: Have You Been Bugged By Graffiti? The Future. The Future of Media supplement, $2: 42$.

-. Breakthrough broadcast medium in the limelight. The Future. The Future of Media supplement, 2:49.

van Heerden, NJ. 2001 The role of sport sponsorships in South Africa Unpublished DCom Thesis, University of Pretoria.

Walker, S. 2000. Media's move into realm of ideas. The Future. The Future of Media Supplement, 2:3. 